\title{
Implementasi Model Pembelajaran Flipped Classroom Guna Meningkatkan Interaksi Belajar Mahasiswa pada Mata Kuliah Manajemen Informasi dan E-Administrasi
}

\author{
Thanthawi Ishak, Rudi Kurniawan, Zamzami Zainuddin
}

Program Studi Ilmu Administrasi Negara, Sekolah Tinggi Ilmu Administrasi (STIA) Nasional)

\section{Edcomtech}

Jurnal Kajian

Teknologi Pendidikan

Volume 4, No 2, Oktober 2019

89-95

Submitted 22-05-2019

Accepted 28-08-2019

Corresponding Author

Rudi Kurniawan

krudi509@gmail.com

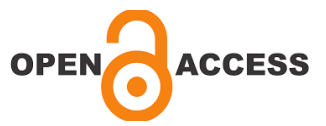

\begin{abstract}
Penelitian ini bertujuan untuk mengidentifikasi efektivitas interaksi mahasiswa dalam pembelajaran mata kuliah Manajemen Informasi dan E-Administrasi dengan menggunakan metode flipped classroom (Kelas terbalik). Penelitian ini dilakukan dengan menggunakan pendekatan penelitian metode campuran. Kuesioner dan wawancara individu digunakan untuk mengumpulkan data. 29 responden dari peserta ajar diberikan kuesioner pada akhir semester dan 10 dari mereka dipilih untuk dilakukan wawancara secara individu. Data yang terkumpul dianalisis menggunakan statistik deskriptif dan analisis data menggunakan SPSS. Hasil penelitian ini menunjukkan bahwa peserta ajar memiliki persepsi positif dalam semua komponen interaksi dalam pembelajaran mata kuliah Manajemen Informasi dan E-Administrasi menggunakan menggunakan metode flipped classroom. Output dari penelitian ini telah memberikan kontribusi bagi sebuah perguruan tinggi dalam mengimplementasikan digital pembelajaran inovatif flipped classroom dengan menggunakan media WhatsApp dan YouTube.
\end{abstract}

Kata Kunci: Flipped classroom, YouTube, WhatsApp, Interaksi belajar, Inovasi pembelajaran

\begin{abstract}
This study aims to identify the effectiveness of student interaction in learning Information Management and E-Administration courses using the flipped classroom method. This research was conducted using a mixed methods research approach. Questionnaires and individual interviews are used to collect data. 29 respondents from teaching participants were given a questionnaire at the end of the semester and 10 of them were selected to be interviewed individually. The collected data were analyzed using descriptive statistics and data analysis using SPSS. The results of this study indicate that teaching participants have positive perceptions in all components of interaction in learning Information Management and E-Administration courses using the flipped classroom method. The output of this research has contributed to a university in implementing digital learning innovative flipped classroom using WhatsApp and YouTube.
\end{abstract}

Keywords: Flipped classroom, YouTube, WhatsApp, Learning interactions, Learning innovation 


\section{PENDAHULUAN}

Pesatnya perkembangan teknologi informasi saat ini menuntut para pengajar, guru atau dosen untuk mampu berinovasi dan beradaptasi dalam penggunaan berbagai metode pembelajaran berbasis digital (Collins \& Halverson, 2018). Oleh karena demikian, sudah menjadi tuntutan bagi para pengajar baik di sekolah maupun perguruan tinggi untuk dapat mengajarkan peserta didik generasi milenial sesuai dengan kebutuhan mereka (learners needs) yang sudah terbiasa menghabiskan waktu bersama gadget dalam mengakses berbagai informasi dan sumber pengetahuan. Salah satu model pembelajaran terbaru era digital adalah blended learning, yaitu penggabungan metode pembelajaran dengan menggunaan media teknologi secara online terutama di luar kelas dan interaksi tatap muka (face-to-face) terutama di dalam kelas (Zainuddin \& Keumala, 2018). Adapaun turunan dari metode blended learning ini disebut dengan metode flipped classroom (Sergis, Sampson, \& Pelliccione, 2018). Metode ini tergolong baru (novelty) dalam dunia pendidikan namun sudah banyak dipraktikkan di berbagai institusi pendidikan dunia dan menghasilkan pembelajaran efektif dan interaktif. Meskipun sebagai model pedagogi terbaru (emerging pedagogy), kajian flipped classroom masih belum popular di Indonesia. Hal ini disebabkan oleh masih kurangnya sumber publikasi yang ditulis dalam Bahasa Indonesia.

Penelitian ini bertujuan untuk menggali potensi implementasi model flipped classroom dan media sosial WhatsApp sebagai upaya meningkatkan interaksi mahasiswa dalam proses belajar-mengajar di perguruan tinggi Indonesia, terutama di luar kelas secara online. Di samping itu, penerapan model ini diharapkan akan mempu memperkenalkan model pembelajaran terbaru pada perguruan tinggi di Indonesia dan menjadi referensi untuk kajian selanjutnya. Flipped classroom secara sederhana didefenisikan sebagai strategi pembelajaran dimana siswa mempelajari materi bejalar melalui video sebelum masuk kelas dan hadir ke kelas untuk berdiskusi dan saling bertukar gagasan (knowledge exchange) (Blau \& Shamir-Inbal, 2017).
Disamping itu, grup WhatsApp akan digunakan dalam penelitian ini sebagai platform pembelajaran untuk diskusi online dan berbagi materi belajar seperti video, jurnal, buku atau referensi lainnya. Mahasiswa juga dapat berdiskusi dan mengakses bahan ajar kapan saja dan dimana saja. Penggunaan media WhatsApp sudah sangat familiar di kalangan mahasiswa sehingga akan memudahkan mereka mengakses berbagai materi dan berinteraksi langsung secara online di luar kelas. Pemanfaatan model flipped classroom, WhatsApp dan video YouTube dalam penelitian ini diharapkan mampu membawa pengaruh positif dalam mentransformasikan model pembelajaran konvensional ke model pembelajaran inovatif sesuai dengan abad-21. Konsep ini juga diharapkan dapat membangun interaksi mahasiswa yang lebih intensif, baik antara mahasiswa dengan mahasiswa atau mahasiswa dengan dosesn di dalam kelas ataupun di luar kelas.

\section{Kajian Pustaka}

Flipped classroom dalam bahasa Indonesia bisa diterjemahkan sebagai "kelas terbalik" adalah strategi pembelajaran yang sedang menjadi tren saat ini dan menjadi isu novelty di berbagai jurnal internasional bereputasi (Blau \& Shamir-Inbal, 2017). Dalam model pembelajaran ini, pengajar akan merekam video mereka mengajar atau bisa juga mengadopsi video dari berbagai sumber seperti Khan Academy, TED-Ed, YouTube, BBC News, National Geographic atau VOA News. Video yang telah direkam akan diunggah ke sebuah platform pembelajaran baik media sosia, Blog, Wiki atau Learning Management System (LMS) (Jovanovic, Mirriahi, Gašević, Dawson, \& Pardo, 2019). Dalam penelitian ini, penulis menggunakan grup WhatsApp sebagai platform atau media belajar di luar kelas. Berbagai video materi kuiah akan bagikan ke dalam platform ini lima hari sebelum dimulai dan mahasiswa diharuskan mempelajarinya (review) sebelum datang ke kelas.

Penelitian ini difokuskan pada interaksi mahasiswa dengan metode flipped classroom. Interaksi adalah komunikasi dan kerja sama di antara semua elemen. Di kelas, mahasiswa 
dapat membangun interaksi dengan teman sejawat (peer-interaction), dosen dan materi ajar. Banyak sekali penelitian yang menekankan pentingnya interaksi mahasiswa dalam kegiatan belajar-mengajar, baik interaksi antar teman sejawat, interaksi dengan pengajar, dan interaksi dengan materi pembelajaran. Interaksi di antara semua komponen dalam proses belajar mengajar sangat diperlukan untuk mencapai tujuan pembelajaran (Asikainen, Blomster, \& Virtanen, 2018). Dalam pembelajaran berbasis teknologi, interaksi memiliki peranan yang sangat signifikan untuk memperkuat komunikasi sosial antara siswa dan pengajar baik di kelas maupun di luar kelas menggunakan berbagai media digital (Asfar \& Zainuddin, 2015).

Berbagai kajian sebelumnya telah menyebutkan bahwa interaksi sosial peserta ajar dalam metode pembelajaran berbasis teknologi lebih efektif dibandingkan dengan interaksi di kelas konvensional tanpa penggunaan media teknologi. Peserta ajar di kelas konvensional hanya efektif berinteraksi secara fisik (face-to-face) saja di dalam kelas, tetapi terbatas di luar kelas (Lin, 2019). Dari berbagai literasi ini dapat diasumsikan bahwa interaksi sosial tidak akan berkurang ketika media teknologi diintegrasikan ke dalam kegiatan belajar-mengajar, terutama dalam model pembelajarn flipped classroom.

Disamping itu, penggunaan media teknologi seperti media sosial, LMS atau video akan membantu siswa berinteraksi dengan mudah dengan semua komunitas baik di dalam maupun di luar kelas. Meskipun demikian, kurangnya interaksi siswa telah menjadi masalah krusial dalam proses belajar-mengajar di berbagai perguruan tinggi Indonesia saat ini. Satu studi menyebutkan bahwa interaksi pengajar-siswa dan siswasiswa yang buruk cenderung membuat kegiatan belajar mengajar menjadi pasif dan tidak efektif (Ainin, Naqshbandi, Moghavvemi, \& Jaafar, 2015).

\section{Kerangka Konsep Penelitian}

Dalam penelitian ini, interaksi mengacu pada teori Moore (1989) di mana peserta ajar membangun interaksi belajar antar sesama, interaksi dengan pengajar, materi ajar dan media teknologi baik di kelas maupun atau di luar kelas. Dalam pembelajaran flipped classroom, mahasiswa sebagai peserta ajar juga akan berinteraksi dengan keempat elemen tersebut. Dalam proses belajar-mengajar, interaksi antara siswa dan instruktur adalah memiliki peran yang sangat penting untuk membuat suasana belajar aktif dan hidup (Blau \& Shamir-Inbal, 2017). Melalui interaksi sesama peserta ajar, proses peer tutoring akan terjadi dimana setiap mahasiswa yang meimiliki kelebihan akan saling berbagi ilmu dengan teman sejawatnya. Interaksi siswa-siswa juga akan mendukung pertukaran informasi antar sesame mereka, berkolaborasi menyelesaian masalah dan membantu mereka memahami isi pembelajaran (Zainuddin \& Perera, 2018). Disamping itu, melalui interaksi peserta ajarpengajar, umpan balik (feedback) dari seorang pengajar bisa langsung diberikan kepada siswa sehingga mereka dapat langsung mengetahui taraf hasil belajar mereka. Kesalahan dan kekurangan dari siswa juga bisa langsung dapat diperbaiki oleh pengajar (Esterhazy \& Damşa, 2019).

Semua interaksi belajar termasuk interaksi dengan materi ajar dan media teknologi akan meningkatkan pemahaman mereka tentang materi yang mereka pelajari. Dalam model pembelajaran flipped classroom ini, peserta ajar tidak hanya berinteraksi dengan teman mereka atau pengajar secara tatap muka di kelas saja, tetapi juga di luar kelas melalui penggunaan media digital seperti Facebook, Twitter, Blog, atau Moodle (Zainuddin \& Perera, 2018). Ini berarti bahwa model pembelajaran flipped classroom dapat membangun budaya belajar yang bukan hanya sesaat di kelas saja, tetapi berkelanjutan setelah proses belajarmengajar di kelas berlangsung.

Interaksi dengan bahan ajar dan media teknologi di luar kelas akan mampu membantu peserta ajar untuk mempelajari materi secara mandiri melalui berbagai sumber seperti video online atau Website (Lai, Hu, \& Lyu, 2018). Para peserta ajar juga dapat membuat catatan tentang apa yang mereka pelajari di luar kelas untuk dibawa dan didisukusikan ketika kelas berlangsung. Bergmann dan 
Sams (2014) menyebutkan bahwa dalam model pembelajaran flipped classroom, siswa tidak hanya menonton video ajar tetapi juga berinteraksi dengan video seperti dapat mengulangi video tersebut beberpa kali jika belum menguasainya. Mereka juga dapat berinteraksi dengan video ajar dimanapun dan kapanpun sebelum masuk kelas.

Desain kerangka konsep peneltian ini didasarkan pada Moore Theory (1989) dan Hillman et al. (1994) untuk mengeksplorasi interaksi belajar mahasiswa pada mata kuliah Manajemen Informasi dan E-Administrasi dengan menggunakan pendekatan model pembelajaran flipped classroom. Menurut Moore (1989), tiga interaksi mendasar harus ditetapkan untuk keberhasilan belajar mengajar dengan pembelajaran berbasis teknologi: interaksi siswa-siswa, interaksi siswa-pengajar dan interaksi siswa-materi ajar. Hillman et al. (1994) menambahkan interaksi antar siswa dengan media teknologi bisa menjadi interaksi keempat untuk melengkapi konsep Moore. Semua interaksi ini adalah elemen yang sangat signifikan untuk diterapkan dalam pendekatan flipped classroom di mana teknologi digunakan sebagai media untuk membagikan materi ajar sebelum masuk kelas dan membangun interaksi onlineantar sesama siswwa di luar kelas

\section{METODE}

Penelitian ini bertujuan untuk mengimplementasikan model pembelajaran flipped classroom pada mata kuliah Manajemen Informasi dan E-Administrasi selama 14 kali pertemuan, dan mengidentifikasi persepsi mahasiswa dalam hal interaksi belajar baik di kelas maupun di luar kelas. Penelitian ini dilaksanakan pada Sekolah Tinggi Ilmu Administrasi (STIA) Nasional. Mata kuliah Manajemen Informasi dan E-Administrasi adalah salah satu mata kuliah wajib yang harus diambil oleh seluruh mahasiswa pada perguruan tinggi ini.

Desain metode campuran (Mixed-method) diimplementasikan sebagai metodologi penelitian. Menurut Creswell, (2008), desain penelitian metode campuran adalah prosedur untuk mengumpulkan, menganalisis, dan "mencampur" metode kuantitatif dan kualitatif dalam satu studi atau serangkaian studi untuk memahami masalah penelitian. Dalam memilih sampel penelitian, peneliti menggunakan metode purposive sampling dimana sampel diambil dengan sengaja dan ditentukan oleh beberpa kriteria khusus, antara lain; belum pernah berpengalaman dengan metode belajar flipped classroom, mahasiswa kelas Manajemen Informasi dan E-Administrasi dan data mendalam bisa didapatkan dari sampel ini. Kesluruahan mahasiswa berjumlah 29 orang, 19 laki-laki dan 10 perempuan, berpartisipasi dalam menjawab kuesioner di akhir proses belajarmengajar atau di akhir semester. Disamping itu, 10 sampel terdiri dari 5 laki-lai dan 5 perempuan dipilih untuk diwawancarai (interview) guna memperoleh data secara mendalam tentang pengalaman belajar flipped classroom.

Kuesioner survey untuk data kuantitatif yang digunakan terdiri dari lima tingkat item Liker scale (1) Sangat tidak setuju (STS), (2) Tidak setuju (TS), (3) Netral (N), (4) Setuju (S), (5) Sangat Setuju (SS). 10 item kuesioner dikategorikan menjadi empat bagian; 2 item untuk interaksi antar sesama peserta ajar, 4 item untuk interkasi peserta ajar-pengajar, 2 item untuk interaksi peserta ajar-materi ajar dan 2 item lainnya untuk interaksi peserta ajar-teknologi. Kuseioner ini terlebih dahulu diberikan pada 10 mahasiswa untuk menguji reliabitas dan mengumpulkan umpan balik mereka mengenai item kuesioner. Hasil dari uji reliabilitas ini menunjukkan alpha Cronbach 0,874. Dengan demikian, kuesioner dalam penelitian ini dianggap reliabel dan dapat diandalkan dalam pengumpulan data. Selain itu, untuk menguji validitas, Item kuesioner juga telah diperiksa oleh para pakar untuk memperoleh masukan. Oleh karena itu, kuesioner juga dianggap valid atau relevan dengan konteks penelitian ini.

Dalam penelitian ini, peneliti menganalisis kedua data secara terpisah, dimulai dengan data kuantitatif dan selanjutnya diikuti oleh data kualitatif. Model analisis ini disebut dengan Explanatory Sequential Design, ini berarti bahwa analisis data kualitatif akan membantu mendukung dan menguraikan analisis 
mendalam tentang data kuantitatif (Creswell, 2008). Data kuesioner dianalisis dalam statistik deskriptif menggunakan perangkat lunak SPSS. Tujuannya adalah untuk meringkas set data tertentu untuk tampilan grafis. 5 skala Likert dari kuesioner diinterpretasikan dalam data ordinal untuk menentukan bahwa satu skor lebih tinggi dari yang lain. Data ordinal biasanya ditafsirkan sebagai satu skor lebih tinggi dari yang lain dan bukan jarak antara titik. Disamping itu, hasil analisis juga dilaporkan dengan persentase, Mean ( $M$ ) dan Standar Deviasi $(S D)$. Analisis wawancara penelitian ini menggunakan langkah step-wise design yang dijelaskan oleh Patton (2002). Prosesnya terdiri dari tiga langkah: (1) Mengumpulkan data mentah; hasil wawancara verbal ditranskripsikan dalam teks, (2) Mengklasifikasikan data mentah ke dalam tema atau ketegori, (3) Melaporkan dan menginterpretasikan laporan akhir secara deskriptif sesuai dengan tema.

\section{HASIL DAN PEMBAHASAN}

Penemuan dari penelitian ini dimulai dengan analisis survei kuesioner dalam bentuk kuantitatif dilanjutkan dengan wawancara sebagai data kualitatif. Dari hasil analisis secara demografi, 29 siswa menyelesaikan survey terdiri dari 19 laki-laki dan 10 perempuan, dan 10 mahasiswa terlibat dalam interview, terdiri dari 5 laki-laki dan 5 perempuan.

\section{Analisis kuantitatif}

Dalam analisis survei kuesioner, peneliti membagi bagian ini menjadi empat bagian yaitu interaksi antar sesama pengajar (Item 1-2), interaksi dengan pengajar (Item 36), interaksi dengan materi ajar (Item 7-8) dan interaksi dengan media teknologi (9-10) (lihat Tabel 1- Tabel 4).

\section{Interaksi sesama peserta ajar}

Analisis quesinoner ini dimulai dengan item 1-2 mengenai interaksi antar sesama peserta ajar. Analisis dari Item 1 menunjukkan bahwa lebih dari $90 \%$ responden menjawab positif bahwa metode flipped classroom dapat membangun interaksi belajar antar sesama mereka baik secara tatap muka di dalam kelas maupun secara online di luar kelas melalui grup
WhatsApp. Nilai rata-rata $(M=4.24, S D=0.636)$ dari penelitian ini juga menunjukkan bahwa telah terbangun interaksi yang baik antar peserta ajar selama proses belajar-mengajar berlangsung. Temuan ini membuktikan bahwa penerapan flipped classroom dengan media belajar video YouTube dan grup WhatsApp tidak mengurangi interaksi sosial mereka dalam belajar. Selain itu, item 2 menunjukkan bahwa mayoritas responden secara positif menyatakan bahwa mereka dapat belajar dan bertukar ide dengan teman sejawat baik di kelas maupun di luar kelas. Nilai rata-rata $(M=4.31, S D=0.66)$ respon para responden juga menunjukkan citra positif terhadap item ini. Tabel 1 berikut merangkum analisis respon peserta ajar tentang pengalaman berinteraksi antar sesama mahasiswa selama proses belajar-mengajar berlangsung dengan persentase, rata-rata $(M)$ dan standar deviasi (SD).

Tabel 1. Analisis statistik deskriptif responden terhadap interaksi belajar antar peserta ajar

\begin{tabular}{|l|l|l|}
\hline \multicolumn{1}{|c|}{ Item } & M & SD \\
\hline $\begin{array}{l}\text { Interaksi antar sesama } \\
\text { peserta ajar }\end{array}$ & & \\
\hline $\begin{array}{l}\text { 1. } \\
\text { Belajar dengan metode } \\
\text { flipped classroom } \\
\text { membuat saya lebih } \\
\text { banyak berinteraksi } \\
\text { dengan siswa lainnya baik } \\
\text { di kelas maupun di luar } \\
\text { kelas }\end{array}$ & 4.24 & .636 \\
\hline $\begin{array}{l}\text { 2. } \\
\text { Saya merasa banyak } \\
\text { belajar dari siswa lain baik } \\
\text { di kelas maupun di luar } \\
\text { kelas }\end{array}$ & 4.31 & .66 \\
\hline
\end{tabular}

Temuan ini membuktikan bahwa metode flipped classroom atau metode flipped classroomtelah mampu membentuk interaksi sosial yang kuat di antara peserta ajar di mana mereka dapat belajar, mengajar dan bertukar pengetahuan satu sama lain, bukan hanya secara tatap muka saja di kelas, tetapi juga secara online di luar kelas. Metode flipped classroom telah membantu peserta ajar yang memiliki kemampuan akademik rendah untuk belajar dan bertanya kepada teman 
sejawat mereka yang memiliki kemampuan di atas mereka, dan kegiatan ini disebut dengan peer-tutoring.

\section{Interaksi dengan pengajar}

Item 3 menunjukkan bahwa $86.2 \%$ responden merespons positif bahwa mereka dapat berinteraksi dengan pengajar tidak hanya di kelas, tetapi juga di luar jam kelas melalui grup media sosial WhatsApp. Namun, hasil ini tidak menunjukkan respons positif yang terlalu tinggi. Demikian juga, skor rata-ratanya $(M=3.83, S D=0.468$ ) menunjukkan bahwa siswa tidak sepenuhnya puas dengan partisipasi pengajar di luar kelas secara online dan tingkat persentase ini bisa dianggap moderat. Oleh karena itu, peneliti menyarankan bahwa pengajar yang mengimplementasikan metode pembelajaran flipped classroom untuk dapat mengalokasikan waktu mereka untuk berinteraksi dengan siswa di luar jam kelas secara online baik melalui media sosial, Blog, atau Moodle.

Selanjutnya, Item 4 melaporkan bahwa $86 \%$ siswa mencatat bahwa pengajar mereka sabar dalam menjelaskan materi ajar yang sedikit dianggap sulit untuk dipahami. Demikian juga, skor rata-rata $(M=3.86, S D=$ 0.516) juga menunjukkan bahwa persentase item ini adalah sedang. Peneliti juga menyarankan kembali bahwa para pengajar yang mengimplementasikan metode ini untuk mampu meningkatkan kesabaran dalam menjelaskan konsep-konsep atau materi ajar yang sedikit rumit kepada siswa. Untuk item 5, 90\% siswa secara positif menyatakan bahwa umpan balik (feedback) yang diberikan oleh dosen di kelas meningkatkan pemahaman mereka tentang materi yang mereka pelajari $(M=4.24, S D=0.636)$.

Selanjutnya, item 6 menunjukkan bahwa 90\% siswa merespons positif bahwa pengajar dapat menjawab pertanyaan mereka tepat waktu. Nilai rata-rata $(M=4.17, S D=0.602)$ juga menunjukkan nilai positif bahwa responden puas dengan respon pengajar terhadap pertanyaan mereka. Temuan ini membuktikan bahwa para peserta ajar dan pengajar atau dosen memiliki interaksi yang baik dalam kegiatan Tanya-jawab baik di kelas maupun diluarkelas. Temuan ini menunjukkan bahwa interaksi antara siswa dan pengajar telah terbangun secara interaktif. Di samping itu, laporan ini juga menunjukkan bahwa pengajar juga telah berhasil memberikan umpan balik (feedback) kepada siswa sebagai proses penilaian formatif (formative assessment) guna meningkatkan kemampuan akademik siswa (Lihat Tabel 2 berikut).

Tabel 2. Analisis statistik deskriptif responden terhadap interaksi belajar peserta ajar - pengajar

\begin{tabular}{|c|c|c|}
\hline Item & $M$ & $S D$ \\
\hline \multicolumn{3}{|l|}{ Interaksi dengan pengajar } \\
\hline $\begin{array}{l}\text { 3. Pengajar meluangkan } \\
\text { waktunya untuk } \\
\text { berinteraksi dengan kami } \\
\text { secara online di luar kelas }\end{array}$ & 3.83 & .468 \\
\hline $\begin{array}{l}\text { 4. Pengajar sabar dalam } \\
\text { menjelaskan materi yang } \\
\text { sulit kami mengerti }\end{array}$ & 3.86 & .516 \\
\hline $\begin{array}{l}\text { 5. Feedback atau masukan } \\
\text { yang diberikan pengajar } \\
\text { membantu saya belajar } \\
\text { lebih baik }\end{array}$ & 4.24 & .636 \\
\hline $\begin{array}{l}\text { 6. Saya puas berinteraksi } \\
\text { dengan pengajar pada } \\
\text { kelas ini }\end{array}$ & 4.17 & .602 \\
\hline
\end{tabular}

\section{Interaksi dengan materi ajar}

Analisis dari item 7 menunjukkan bahwa 93\% siswa memberikan respon positif bahwa mereka dapat dengan mudah berinteraksi dengan materi video ajar di luar kelas. Video ajar dapat dipelajari sesuai kebutuhan mereka seperti, menghentikan sementara (pause) atau memutar ulang (replay) video tersebut. Temuan ini didukung dengan pernyataan Bergmann dan Sams (2014) yang menyatakan penggunaan istilah "berinteraksi dengan video" pada pembelajaran flipped classroom bukan hanya sekedar "menonton video", tetapi juga mengontrol video kuliah tersebut sesuai dengan kebutuhan. Bahkan video tersebut dapat ditonton dimana saja dan kapan saja, dan setiap siswa memiliki kemampuan berbeda dalam memhami ceramah kuliah dari pengajar mereka, maka video rekaman ajar tersebut sangat 
bermanfaat bagi para peserta ajar dengan ragam tingkatan kecerdasan dalam menyerap pelajaran.

Selain itu, item 8 menunjukkan bahwa 90\% peserta ajar memberikan respon positif bahwa mereka dapat dengan mudah membuat catatan sambil menonton video pelajaran di luar jam pelajaran $(M=4,35, S D=1,050)$. Dari penemuan ini, peneliti dapat menyimpulkan bahwa dengan menonton video ceramah di luar kelas, siswa dapat dengan mudah membuat catatan sebelum dating ke kelas dan lebih siap untuk berdiskusi atau bertanya jawab ketika di kelas nantinya (Lihat Tabel 3 berikut).

\section{Tabel 3. Analisis statistik deskriptif responden terhadap interaksi belajar peserta ajar - materi ajar}

\begin{tabular}{|c|c|c|c|}
\hline & Item & $M$ & $S D$ \\
\hline \multicolumn{4}{|c|}{ Interaksi dengan materi ajar } \\
\hline 7. & $\begin{array}{l}\text { Menggunakan video ajar } \\
\text { YouTube sebelum/ di luar } \\
\text { kelas membuat saya mampu } \\
\text { mengontrolnya sesuai } \\
\text { kebutuhan saya seperti pause, } \\
\text { stop, replay atau fast-forward } \\
\text { (percepat/ perlambat) }\end{array}$ & 4.26 & .649 \\
\hline 8. & $\begin{array}{l}\text { Belajar menggunakan video ajar } \\
\text { YouTube sebelum/ di luar kelas } \\
\text { membuat saya lebih mudah } \\
\text { untuk meembuat catatatan } \\
\text { sebelum datang ke kelas }\end{array}$ & 4.21 & .620 \\
\hline
\end{tabular}

\section{Interaksi dengan media teknologi}

Untuk interaksi antara siswa dengan media teknologi, peneliti menemukan jawaban responden bahwa menyebutkan bahwa $87 \%$ siswa merespons positif bahwa teknologi online membuatnya membuat mereka mduah untuk berinteraksi dengan siswa lain terutama di luar kelas secara online (item 9). Dengan kata lain, dengan pemanfaatan media digital seperti WhatsApp, siswa akan dengan mudah menjalin interaksi di luar kelas dengan teman sejawat mereka, pengajar, atau materi ajar dari berbagai sumber online. Selanjutnya, item 10 juga menyebutkab bahwa 91\% siswa yang sangat tidak setuju bahwa penggunaan media teknologi dalam pembelajaran membuat mereka lebih mudah untuk berkomunikasi dengan pengajar mereka atau dosen. Tabel 4 berikut merangkum analisis respon peserta ajar tentang pengalaman berinteraksi antar mahasiswa dengan materi ajar selama proses belajar-mengajar berlangsung dengan persentase, rata-rata $(M)$ dan standar deviasi $(S D)$.

Tabel 4. Analisis statistik deskriptif responden terhadap interaksi belajar peserta ajar - media teknologi

\begin{tabular}{|c|c|c|}
\hline Item & $M$ & $S D$ \\
\hline \multicolumn{3}{|l|}{ Interaksi dengan media teknologi } \\
\hline $\begin{array}{l}\text { 9. Penggunaan media teknologi } \\
\text { membuat saya lebih mudah } \\
\text { berinteraksi dengan siswa } \\
\text { lainnya terutama di luar kelas }\end{array}$ & 4.31 & .66 \\
\hline $\begin{array}{l}\text { 10. Penggunaan media teknologi } \\
\text { membuat saya lebih mudah } \\
\text { berkomunikasi dengan pengajar } \\
\text { terutama di luar kelas }\end{array}$ & 4.14 & .693 \\
\hline
\end{tabular}

Dari 10 item analisis data questioner ini, dapat disimpulkan bahwa hampir semua peserta ajar memiliki interaksi yang baik atau positif dengan semua elemen interaksi yang dicetuskan oleh Moore (1989), baik antar mahasiswa sendiri (peer-interaction), dosen (learner-instructor interaction), bahan ajar (learner-content interaction) dan media teknologi (learner-technology interaction). Interaksi ini tidak hanya terbangun di dalam kelas saja, tetapi juga juga di luar kelas.

\section{Analisis data kualitatif}

Pendekatan kualitatif ditujukan sebagai metode untuk melakukan penelitian yang lebih mendalam tentang persepsi mahasiswa dalam hal interaksi mereka dalam pembelajaran flipped classroom. Analisis ini juga digunakan untuk mendukung hasil kuantitatif dari survei /kuesioner sebelumnya. Sampel yang diambil dalam wawancara ini adalah sepuluh orang mahasiswa. Para mahasiswa ini diminta untuk menggambarkan interaksi mereka selama belajar melalui metode flipped classroom. Empat tema umum muncul selama analisis wawancara ini dan sangat relevan dengan interaksi model Moore (1989), yaitu: (1) 
interaksi antar sesama peserta ajar atau mahasiswa, (2) interaksi dengan pengajar atau dosen, (3) interaksi dengan materi ajar dan (4) interaksi dengan media teknologi.

\section{Interaksi belajar antar sesama peserta ajar}

Interaksi dengan teman sekelas atau sejawat dinilai sangat penting dalam proses belajar-mengajar terutama pada perguruan tinggi. Seperti yang dinyatakan oleh Nguyen, Cannata dan Miller (2018), kurangnya interaksi antar teman sejawat akan membuat kegiatan belajar-mengajar menjadi tidak efektif dan pasif karena mereka tidak memiliki kesempatan untuk melatih pikiran kritis mereka, menyelesaikan masalah dalam kelompok atau bertukar gagasan. Secara khusus, semua responden wawancara dalam penelitian ini mengakui bahwa metode flipped classroom telah sukses membangun interaksi yang aktif antar teman sejawat dalam kegaiatn belajr-mengajar mata kuliah Manajemen Informasi dan E-Administrasi, baik interaksi di dalam kelas maupun secara virtual di luar kelas. Contoh model respon positif seorang responden wawancara adalah sebagai berikut:

"Saya sangat setuju, dalam metode belajar ini, saya memiliki kesempatan untuk berbicara lebih banyak dibandingkan dosen dan lebih banyak berdiskusi dengan temanteman, artinya tidak pasif hanya mendengarkan ceramah dosen saja"

Respon positif lainnya adalah kegiatan diskusi dan interaksi di luar kelas, terutama online melalui grup WhatsApp. Beberapa model respon positif terhadap tema ini adalah sebagai berikut:

"Metode belajar ini sangat bagus, membuat kami memiliki lebih banyak waktu untuk berdiskusi dengan temanteman baik di dalam maupun di luar kelas, bisa lebih banyak waktu untuk bertukar pikiran"

Disamping itu, beberapa responden juga menyebutkan bahwa setelah memepelajari video materi pembelajaran di luar kelas, mereka dapat menyiapkan catatan pertanyaan untuk dibawa dan didiskusikan di kelas.

\section{Interaksi dengan pengajar}

Selain itu, melalui metode flipped classroom, siswa memiliki lebih banyak kesempatan untuk berinteraksi dengan dosen. Hal in sesuai dengan pernyataan Zainuddin dan Perera (2019) bahwa dalam konteks kegiatan belajar-mengajar, interaksi antara siswa dan pengajar memiliki peran yang sangat penting dalam memberikan kontribusi prestasi emosional, sosial dan akademik kepada siswa. Siswa juga akan menunjukkan rasa nyaman (comfortable), percaya diri (confident) dan senang (fun) jika interaksi dengan pengajar berjalan dengan baik. Dari hasil analisis wawancara dalam penelitian ini, para responden menyatakan secara bahwa dengan metode flipped classroom memberikan kesempatan yang banyak bagi mereka untuk berdiskusi dan berinteraksi dengan dosen mereka dan sangat membantu mereka meningkatkan kualitas diri melalui feedback yang diberikan dosen secara langsung baik kelompok maupun individu.

"Ketika saya keliru menjelaskan suatu konteks, dosen akan langsung memberikan koreksi tanpa menyalahkan pernyataan saya," ujar salah seorang responden.

Pernyataan lain diungkapkan oleh saalah satu responden yang membandingkan pengalamannya berinteraksi dengan dosen pada kelas flipped classroom ini dengan kelas metode tradisional lainnya.

Sementara seorang responden lain menyatakan bahwa penilaian formatif (formatif assessment) atau kuis harian di setiap memulai kelas telah memotivasi mereka untuk mempelajri video ajar sebelum masuk kelas.

\section{Interaksi dengan materi atau bahan ajar}

Selain interaksi dengan pengajar, mahasiswa juga dapat menjalin interaksi yang baik dengan materi pembelajaran dari berbagai sumber terutama video YouTube. Rekaman video ajar dalam YouTube sangat membantu mereka mengulang materi sesuai dengan kebutuahn mereka, kapanpun dan dimanapun sebelum kelas berlangsung. Hampir semua responden menyebutkan 
bahwa mereka dapat dengan mudah memahami konten dalam video materi tersebut dengan mengulang sesuai kebutuhan dan membuat catatan pertanyaan untuk didiskusikan di kelas. Contoh pernyataan positif responden adalah sebagai berikut:

"Materi yang diupload dalam YouTube bagus dan sangat mudah dipahami, tidak membosankan untuk ditonton, saya bisa menonton dengan cara saya sendiri, menulis catatan, puase dan replay sebentar ketika saya tidak mengerti"

Responden lain juga menyebutkan tentang durasi video ceramah yang singkat membuat mereka mudah memahami isi dari video tersebut dan tidak membosankan. Pernyataan positif lainnya datang dari mahasiswa yang sibuk bekerja atau part-time student dimana penggunaan penggunaan video ajar YouTube sangat membantu mereka mengulang kembali pelajaran setelah kelas usai atau saat mereka berada di tempat kerja.

\section{Interaksi dengan media teknologi}

Implementasi metode flipped classroom pada kelas Manajemen Informasi dan E-Administrasi ini juga membuat mahasiswa lebih mengenal dan terbiasa menggunakan teknologi sebagai media dan sumber belajar. Mahasiswa dapat dengan mudah mengakses materi pembelajaran di luar kelas dari berbagai sumber digital seperti video online YouTube dan berbagai sumber Website lainnya.

Sementara responden lainnya menyebutkan bahwa ini adalah pengalaman pertama kalinya menggunakan media teknologi seperti YouTube dan grup WhatsApp dalam kegiatan belajar di universitas. Biasanya interaksi dengan mahasiswa atau dosen pengajar hanya berlangsung di kelas saja secara tatap muka.

"Ya, sekarang saya lebih banyak tau tentang berbagai materi pembelajaran di YouTube dan di web yang bisa saya pelajari kapan saja, tanpa harus menunggu informasi atau bahan kuliah dari dosen"

\section{SIMPULAN}

Kesimpulan yang dapat diambil dari peneltian sederhana ini adalah implementasi model pembelajaran flipped classroom telah sukses membangun budaya interaksi yang baik dengan semua elemen baik antar sesama peserta ajar, dengan pengajar, materi ajar dan media teknologi. Persepsi positif responden tidak hanya dikonfirmasi dari data kuesioner saja, tetapi juga dari hasil wawancara dengan beberapa responden. Hasil temuan dari peneltian ini sangat relevan dengan teori Moore (1989) dan Hillman et al. (1994) yang menyebutkan bahwa dalam proses belajar-mengajar, interaksi seluruh elemen dalam komunitas pembelajaran seperti interaksi siswa-siswa, interaksi siswapengajar, interaksi siswa-materi ajar dan interaksi siswa-teknologi memiliki peran yang sangat signifikan dalam kesuksesan belajar siswa baik emosional maupun akademik. Membangun interaksi pada semua elemen ini akan meningkatkan kualitas kegiatan belajar mengajar semakin produktif dan interaktif. Temuan dari penelitian ini sejalan dengan banyak penelitian sebelumnya tentang implemantasi metode flipped classroomdi dimana peserta ajar mampu membangun interaksi belajar yang baik dengan berbagai elemen, baik di dalam kelas maupun di luar kelas. Luo, Yang, Xue, dan Zuo (2019) misalnya menyebutkan dalam penelitiannya bahwa peserta ajar dapat membangun interaksi yang baik dengan teman sejawat mereka dan melatih mereka memecahkan masalah dalam kolompok dengan saling bertukar gagasan.

Peneliti percaya bahwa hasil dari studi ini bisa menjadi referensi bagi pengajarpengajar di perguruan tinggi terutama di Indonesia dalam mentransformasikan proses belajar-mengajar di kelas dari kegiatan yang berpusat pada pengajar (teacher-centered) ke yang berpusat pada peserta ajar (studentcentered) seperti metode flipped classroom ini. Disamping itu, studi ini juga akan menjadi referensi bagi peserta ajar terutama mahasiswa di perguruan tinggi dalam memahami konsep belajar flipped classroom dan model-model interaksi dalam kegiatan belajar-mengajar. Pengenalan tentang media belajar seperti video dan sumber- 
sumber belajar digital lainnya juga akan membantu menumbuhkan keterampilan belajar mahasiswa di luar kelas secara mandiri (self-paced learning skill) (Zainuddin, Habiburrahim, Muluk, \& Keumala, 2019). Dengan menjamurnya media teknologi digital atau Internet, distribusi video ajar melalui YouTube telah menjadi isu terbaru bukan hanya dalam ranah pendidikan, tetapi juga di berbagai bidang lainnya.

\section{DAFTAR PUSTAKA}

Asfar, N., \& Zainuddin, Z. (2015). Secondary students' perceptions of information, communication and technology (ICT) use in promoting self directed learning in Malaysia. The Online Journal of Distance Education and E-Learning, 3(4), 67-82.

Asikainen, H., Blomster, J., \& Virtanen, V. (2018). From functioning communality to hostile behaviour: students' and teachers' experiences of the teacherstudent relationship in the academic community. Journal of Further and Higher Education, 42(5), 633-648.

Bergmann, J., \& Sams, A. (2014). Flipped learning: Maximizing face time. $T+D$ Magazine, 68(2), 28-31.

Blau, I., \& Shamir-Inbal, T. (2017). Redesigned flipped learning model in an academic course: The role of cocreation and co-regulation. Computers \& Education, 115, 69-81. https://doi. org/10.1016/j.compedu.2017.07.014.

Collins, A., \& Halverson, R. (2018). Rethinking education in the age of technology: The digital revolution and schooling in America. Teachers College Press.

Creswell, J. W. (2008). Educational research: Planning, conducting, and evaluating quantitative and qualitative research (3rd ed.). Upper Saddle River, NJ: Prentice Hall.

Esterhazy, R., \& Damşa, C. (2019). Unpacking the feedback process: an analysis of undergraduate students' interactional meaning-making of feedback comments. Studies in Higher Education, 44(2), 260-274.

Hillman, D. C. A., Willis, D. J., \& Gunawardena, C. N. (1994). Learner-interface interaction in distance education: An extension of contemporary models and strategies for practitioners. American Journal of Distance Education, 8(2), 30-42.

Jovanovic, J., Mirriahi, N., Gašević, D., Dawson, S., \& Pardo, A. (2019). Predictive power of regularity of pre-class activities in a flipped classroom. Computers \& Education, 134, 156-168.

Lai, C., Hu, X., \& Lyu, B. (2018). Understanding the nature of learners' out-of-class language learning experience with technology. Computer Assisted Language Learning, 31(1-2), 114-143.

Lin, Y. T. (2019). Impacts of a flipped classroom with a smart learning diagnosis system on students' learning performance, perception, and problem solving ability in a software engineering course. Computers in Human Behavior, 95, 187-196.

Luo, H., Yang, T., Xue, J., \& Zuo, M. (2019). Impact of student agency on learning performance and learning experience in a flipped classroom. British Journal of Educational Technology, 50(2), 819831.

Moore, M. (1989). Three types of interaction. American Journal of Distance Education, 3(2), 1-6.

Nguyen, T. D., Cannata, M., \& Miller, J. (2018). Understanding student behavioral engagement: Importance of student interaction with peers and teachers. The Journal of Educational Research, 111(2), 163-174.

Patton, M. Q. (2002). Qualitative research and evaluation methods (3rd ed.). London: Sage.

Sergis, S., Sampson, D. G., \& Pelliccione, L. (2018). Investigating the impact of Flipped Classroom on students' learning experiences: A Self-Determination Theory approach. Computers in Human Behavior, 78, 368-378.

Zainuddin,Z., \& Keumala, C. M. (2018). Blended learning method within Indonesian higher education institutions. Jurnal Pendidikan Humaniora, 6(2), 69-77.

Zainuddin, Z., \& Perera, C. J. (2018). Supporting students' self-directed learning in the 
flipped classroom through the LMS TES BlendSpace. On the Horizon, 26(4), 281290.

Zainuddin, Z., Habiburrahim, H., Muluk, S., \& Keumala, C. M. (2019). How do students become self-directed learners in the EFL flipped-class pedagogy? A study in higher education. Indonesian Journal of Applied Linguistics, 8(3), 678-690.

Zainuddin, Z., \& Perera, C. J. (2019). Exploring students' competence, autonomy and relatedness in the flipped classroom pedagogical model. Journal of Further and Higher Education, 43(1), 115-126. 